\title{
Replication of a herpes-like virus in larvae of the flat oyster Tiostrea chilensis at ambient temperatures
}

\author{
P. M. Hine*, B. Wesney, P. Besant \\ National Institute of Water and Atmospheric Research, PO Box 14-901, Kilbirnie, Wellington, New Zealand
}

\begin{abstract}
Veligers removed from brooding Tiostrea chilensis (Philippi, 1845) experienced -95\% mortalities over 3 to $4 \mathrm{~d}$ at 16 to $18^{\circ} \mathrm{C}$ that appeared to be associated with a herpes-like virus. Ultrastructural observations of post-removal veligers showed the presence of early viral replication or putative latent stages at $4 \mathrm{~h}$, all stages of replication at low levels at $24 \mathrm{~h}$, which increased to high levels at $48 \mathrm{~h}$, followed by mortalities at $72 \mathrm{~h}$ onwards. Initially, infected interstitial or epithelial cells had an enlarged nucleus with a wavy outline in which heterochromatin was marginated. With continued increase in size, nuclei became smooth in outline with reduction or loss of heterochromatin. Capsids with lucent cores (LCC) and empty capsids appeared in the nucleus, often in association with tubular structures $\sim 65 \mathrm{~nm}$ in diameter that were composed of subunits in a helical configuration that contained a tubular core $\sim 35 \mathrm{~nm}$ in diameter. Empty capsids and LCC sometimes occurred in paracrystalline arrays. Partial nucleolar disaggregation and encapsidation of dense fibrillar material preceded envelopment entering and de-envelopment leaving the perinuclear cisterna, tegumentation in cytoplasmic vesicles, and egress. Groups of dense cytoplasmic filaments 30 to $35 \mathrm{~nm}$ in diameter occurred in some infected cells. Apparently normal cells with a few intranuclear empty capsids and/or LCC at 4 h postremoval may represent latent infections. Replication was not observed in larvae held at 24 to $27^{\circ} \mathrm{C}$, but a few cells had enlarged hypochromatic karyolytic nuclei, and 1 to 2 capsids were observed in them, at $48 \mathrm{~h}$. Viral replication was similar to that of ranid herpesvirus 1 (Lucké tumour) infections. This is the fifth ostreid species from which herpesviruses have been reported.
\end{abstract}

KEY WORDS: Herpesvirus - Mortality - Oysters - Tiostrea chilensis - Replication - Ultrastructure Cytopathology $\cdot$ Latency

\section{INTRODUCTION}

Replication of herpes-like viruses has been reported from Crassostrea gigas larvae (Hine et al. 1992, Nicolas et al. 1992, Le Deuff et al. 1994, 1995, 1996, Renault et al. 1994b, 1995) and spat (Renault et al. 1994a), Crassostrea virginica adults (Farley et al. 1972), Ostrea edulis spat (Comps \& Cochennec 1993) and Ostrea angasi adults (Hine \& Thorne 1997). Mortalities are usually associated with elevated temperatures (Farley et al. 1972, Hine et al. 1992, Nicolas et al. 1992, Renault et al. 1994a, b, 1995, Le Deuff et al. 1996), with only low levels of virogenesis at lower temperatures (Farley et al. 1972, Le Deuff et al. 1996). Details of replication

•E-mail: m.hine@niwa.cri.nz vary between species, but it is not known whether 1 or more herpes-like viruses are involved.

To investigate whether herpes-like virus transmission can occur between larval Crassostrea gigas and larval flat oysters Tiostrea chilensis, we cohabited larvae at 24 to $27^{\circ} \mathrm{C}$, the permissive temperature for $C$. gigas herpesvirus replication (Hine et al. 1992, Le Deuff et al. 1996). Larvae were also cohabited at the C. gigas virus non-permissive temperature of 16 to $18^{\circ} \mathrm{C}$, and larvae of both species were cultured separately at both temperature ranges, as controls. Two successive cohabitation experiments had to be terminated in $<4 \mathrm{~d}$ because of high mortalities among flat oysters, including the controls. A further attempt at culturing flat oyster larvae alone at both temperatures also had to be terminated in $<4 \mathrm{~d}$ because of high ( 80 to $90 \%$ mortalities. Examination of moribund flat oyster 
larvae held at 16 to $18^{\circ} \mathrm{C}$ showed the presence of herpes-like viruses and, late in the experiment, numerous bacteria. A fourth attempt at holding flat oyster bronds at 16 to $18^{\circ} \mathrm{C}$ did not result in mortalities.

This paper describes the replication and course of infection of a herpes-like virus in Tiostrea chilensis larvae at 16 to $18^{\circ} \mathrm{C}$, and the associated cytopathology, and considers whether the virus occurs as a latent infection in oysters.

\section{MATERIALS AND METHODS}

The data presented are based on 2 cohabitation experiments and the third experiment with only Tiostrea chilensis larvae. Flat oysters $T$. chilensis were collected from Wellington harbour by divers, opened, and late stage veligers from 3 to 5 broods were pooled. Larvae of Crassostrea gigas were obtained from natural spawning at the hatchery at Mahurangi, the site of earlier herpesvirosis (Hine et al. 1992). Larvae were placed into 8 tanks, 4 of which were stocked at 1 larva $\mathrm{mi}^{-1}$ at 16 to $18^{\circ} \mathrm{C}$, with 4 other tanks stocked at 5 larvae $\mathrm{ml}^{-1}$ at 24 to $27^{\circ} \mathrm{C}$. These densities span the 3 larvae $\mathrm{ml}^{-1}$ used by Le Deuff et al. (1994). C. gigas larvae were always stocked at the same densities as $T$. chilensis larvae. In the third and fourth experiments in which $T$. chilensis Iarvae were cultured alone, larvae were stocked at 5 larvae $\mathrm{ml}^{-1}, T$. chilensis and $C$. gigas larvae were separated by a $25 \mu \mathrm{m}$ mesh gauze membrane. UV-filtered seawater was used and larvae held without feeding to reduce bacterial contamination. Flat oyster larvae have rich lipid reserves and can survive without feeding for several days. On initial removal, and at $4,8,16,24,48,72$ and $80 \mathrm{~h}$, a small sample of larvae of each species swimming in the lower water column was fixed in $2.5 \%$ glutaraldehyde in $0.22 \mu \mathrm{m}$ filtered seawater, and processed for transmission electron microscopy (TEM) as previously described (Hine et al. 1992). At 24, 48, 72 and $96 \mathrm{~h}$, the living and dead larvae in each tank were gently mixed, and the proportion of live larvae to dead larvae among 50 larvae/ time determined by trypan blue exclusion. Subsequently a fourth experiment was carried out in which larvae from 3 oysters were maintained separately at 16 to $18^{\circ} \mathrm{C}$ for $6 \mathrm{~d}$.

\section{RESULTS}

\section{Mortality}

The mortality rates over 1 to $3 \mathrm{~d}$ among Tiostrea chilensis larvae in cohabitation experiments were similar in each tank at both temperatures (Fig. 1), and

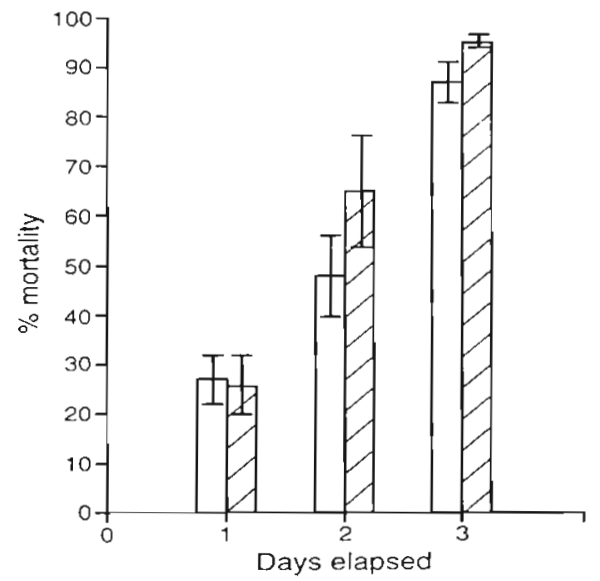

Fiy. 1. Tiostrea chilensis. Daily mortality at 16 to $18^{\circ} \mathrm{C}$ (open histogram) and 24 to $26^{\circ} \mathrm{C}$ (hatched histogram) based on 6 tanks at each time and temperature

from $2 \mathrm{~d}$ onwards bacterial contamination was apparent in both groups. Similar mortality rates, but less bacterial contamination, occurred in the third experiment in which $T$. chilensis larvae were cultured separately. In contrast, in the fourth experiment no mortality resulted over $6 \mathrm{~d}$ and TEM failed to show any signs of viral infection. No mortalities occurred among cohabited and control Crassostrea gigas larvae, and no viruses were observed by TEM. The description below is therefore based on $T$. chilensis infections.

\section{Pathogenesis and virogenesis at 16 to $18^{\circ} \mathrm{C}$}

Virus replication was common in mantle epithelial and interstitial cells, but in digestive tract epithelial cells intranuclear developmental stages were less common. Normal mantle epithelial and interstitial cells had a central elongated ovoid nucleus with a few large islets of heterochromatin, blocks of marginated heterochromatin, and a prominent round nucleolus comprising a dense nucleolonema enclosing a lighter pars amorpha (Fig. 2a). The cytoplasm contained a few long strands of rough endoplasmic reticulum ( $\mathrm{rER}$ ), many ribosomes, Golgi cisternae, and a few mitochondria.

Replication occurred in the followingtstages; the temporal occurrence of stages is shown in Table 1. Sizes given are based on 50 measurements. In stage $I_{\text {, the }}$ nuclei of a few apparently normal interstitial cells contained 1 to 4 empty capsids per section, pentagonal or hexagonal in cross-section [Fig. 2a (inset)], or capsid-like particles $97 \pm 6 \mathrm{~nm}$ in diameter enclosing electron-lucent ring-shaped cores $55 \pm 4 \mathrm{~nm}$ in diameter (lucent core capsids, LCC). Stage II cells had normal nuclei, but either virions apparently entering the cell (Fig. 3), or nucleocapsids (Fig. 4) and empty capsids in the cyto- 

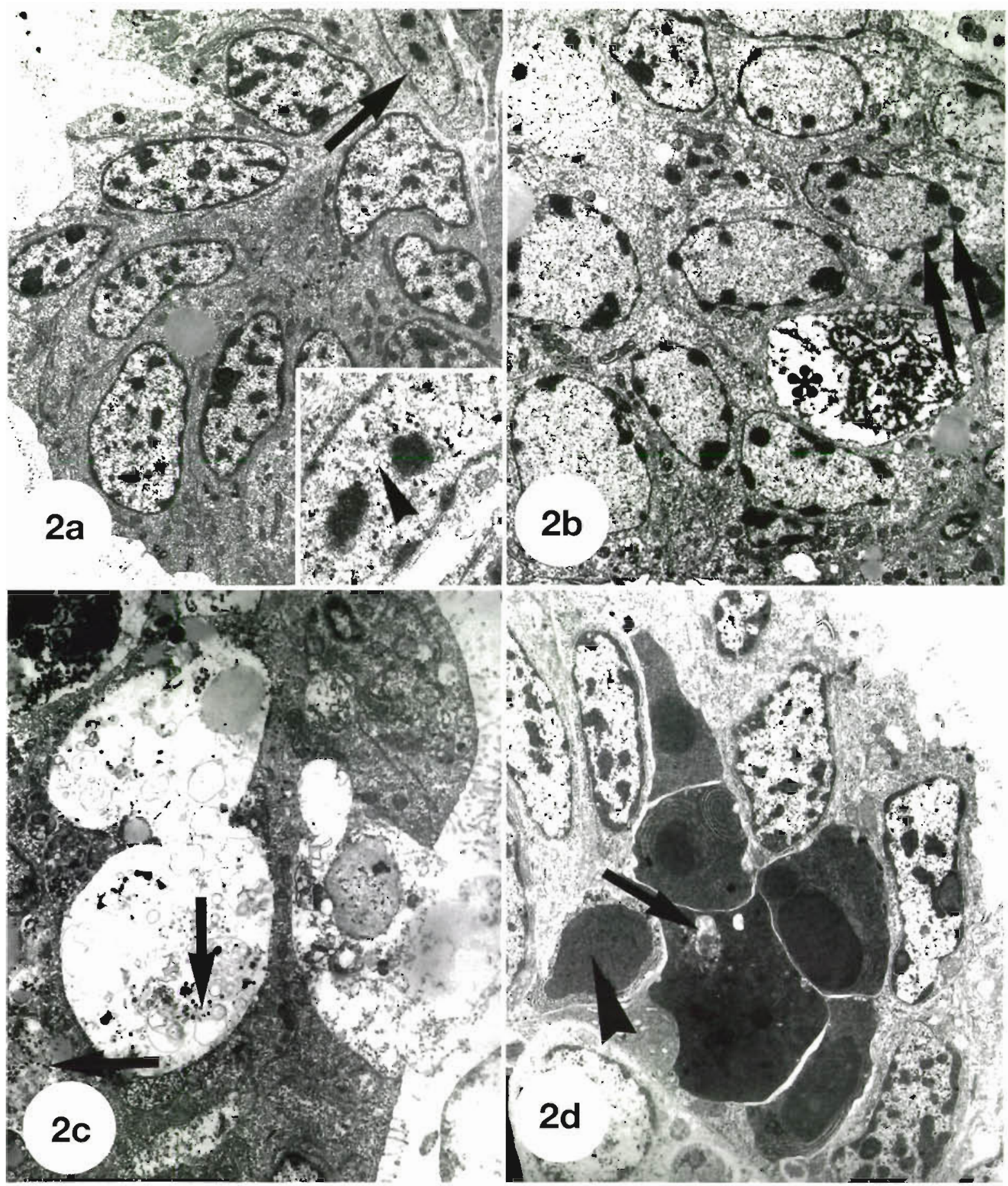

Fig. 2. Tiostrea chilensis. Appearance of mantle epithelial and interstitial cells; 16 to $18^{\circ} \mathrm{C}$ (a) Apparently normal epithelial and interstitial cells with nuclei containing a nucleolus, islets of heterochromatin $(4 \mathrm{~h}$ ), $\times 4430$ Inset. Nucleus of a cell (arrow $1 \mathrm{n}$ Fig $2 \mathrm{a}$ ) containing an empty capsid (arrowhead in inset), $\times 10500$ (b) Margination of heterochromatin in interstitial cell nuclei, sometimes into small lobes (arrows). Most cells at stage III, and 1 lysed (stage V) cell ( $\$$ ) (2 d), $\times 4340$ (c) Spaces left by lysed (stage V) interstitial cells, containing cellular debns and vinons (arrows) ( $2 \mathrm{~d}$ ); $\times 5030$. (d) Cluster of hyperdense (stage VI) interstıtral cells, one with only a dense nucleus (arrowhead) and one containing empty capsids (arrow) ( 3 d); $\times 6450$

plasm. Nucleocapsids also occurred in secondary lysosomes near the apical surface of digestive tract epithelıal cells (Fig. 5), suggesting they had entered the cell from the gut lumen. Stage III included all nuclear stages: (a) nuclear membrane proliferation and folding: (b) heterochromatin margination, of ten into lobes, with sub- 
Table 1. Herpes-like virus in Tiostrea chilensis. The numbers of cells at infection stages I to VI in relation to temperature and sampling time. Based on 2 sections through 5 larvae/ time/temperature, each examined for $15 \mathrm{~min}$. Descriptions of the stages are given in 'Results'

\begin{tabular}{|c|c|c|c|c|c|c|}
\hline \multirow{2}{*}{$\begin{array}{l}\text { Time } \\
\text { fixed }\end{array}$} & \multicolumn{6}{|c|}{ Stages } \\
\hline & I & II & III & IV & V & VI \\
\hline \multicolumn{7}{|c|}{ Ambient $16-18^{\circ} \mathrm{C}$} \\
\hline $\mathrm{Oh}$ & 2 & & & & & \\
\hline $4 \mathrm{~h}$ & 4 & 2 & 2 & & 1 & 1 \\
\hline $8 \mathrm{~h}$ & & 1 & & & & \\
\hline $16 \mathrm{~h}$ & & & & & 3 & 1 \\
\hline $24 \mathrm{~h}$ & 3 & & 6 & 2 & 8 & 6 \\
\hline $36 \mathrm{~h}$ & & & 8 & 8 & 2 & 1 \\
\hline $48 \mathrm{~h}$ & & 1 & 42 & 30 & 14 & 1 \\
\hline $72 \mathrm{~h}$ & & & 2 & 4 & 1 & 2 \\
\hline $80 \mathrm{~h}$ & & & & & & \\
\hline \multicolumn{7}{|c|}{ Elevated $24-27^{\circ} \mathrm{C}$} \\
\hline $0 \mathrm{~h}$ & 1 & & & & & \\
\hline $4 \mathrm{~h}$ & & 6 & & & 3 & \\
\hline $8 \mathrm{~h}$ & 1 & & & & & \\
\hline \multicolumn{7}{|l|}{$16 \mathrm{~h}$} \\
\hline \multicolumn{7}{|l|}{$24 \mathrm{~h}$} \\
\hline \multicolumn{7}{|l|}{$36 \mathrm{~h}$} \\
\hline $48 \mathrm{~h}$ & & & 3 & & & \\
\hline $80 \mathrm{~h}$ & & & & & & \\
\hline
\end{tabular}

sequent reduction or loss of chromatin (Fig. 2b); (c) partial nucleolar disaggregation into an unravelled elongated strands of nucleolonema in close apposition to heterochromatin (Fig. 6), with eventual fragmentation of the nucleolonema; (d) appearance of groups of perichromatin granules and a dense body with dark granular content (Fig. 7); (e) presence of LCC (Figs. 7 \& 9) and empty capsids $97 \pm 5 \mathrm{~nm}$ in greatest diameter; (f) appearance of dense flocculent material (Fig. 8) which became encapsidated (Fig. 8 inset); ( $g$ ) formation of a rod around which a dense core formed; (h) occasional occurrence of a large ovoid body of fine granular material (Fig. 10); (i) occurrence of tubular structures (TS), comprising an outer tubule $66 \pm 12 \mathrm{~nm}$ and inner tubule $30 \pm$ $5 \mathrm{~nm}$ in diameter (Figs. 7, $9 \& 10$ ), with a helical substructure in the outer tubule. These sometimes extended from the nuclear membrane across the nucleus to the nuclear membrane opposite. Transverse sections of TS showed a tube within a tube arrangement similar in appearance to LCC, which were usually abundant near TS (Fig. 8). Tubule components occasionally rearranged to form tubules 95 to $100 \mathrm{~nm}$ in width (Fig. 11). In $\sim 5 \%$ of 100 infected cells, groups of TS surrounded large paracrystalline arrays comprising mainly LCC, but also some empty capsids, and a few capsids with partially formed cores and nucleocapsids $107 \pm 6 \mathrm{~nm}$ with nucleoids $62 \pm 4 \mathrm{~nm}$ in diameter (Fig. 9).

At stage IV, development in the cytoplasm was apparent. Nucleocapsids were enveloped in folds of the inner nuclear membrane, which sometimes formed intranuclear sacs (Fig. 12). The nuclear membrane was often dilated due to a dense matrix and contained bilaminar vesicles $70 \mathrm{~nm}$ in diameter (Fig. 9), which also occurred in rER, with which the perinuclear cisterna appeared to be continuous. Ribosomes were arrayed along the cytoplasmic face of the outer nuclear membrane. Mitochondria appeared normal. Large concentric arrays of $r E R$ were rarely seen. Bundles of dense cytoplasmic filaments 30 to $35 \mathrm{~nm}$ in width occurred in $\sim 5 \%$ of 100 infected cells (Fig. 13), but were never observed in apparently uninfected cells.

Nucleocapsids were present in the cytoplasm, but empty capsids and LCC rarely occurred in the cytoplasm, except following karyolysis. Nucleocapsids were in contact with vermiform smooth vesicles containing moderately osmiophilic materidi, u enveluped in ovoid vesicles containing a similar substance (Fig. 14). At this stage a tegument became apparent between the capsid and envelope. The vesicular material appeared to condense, leaving tegumented virions in lucent vacuoles. Empty capsids and LCC did not enter vesicles or become enveloped. Apparent budding from the plasma membrane was infrequently observed (Fig. 15), but extracellular virions containing capsids $101 \pm 9 \mathrm{~nm}$, enclosing nucleoids $63 \pm 5 \mathrm{~nm}$, were abundant (Fig. 16).

At stage $V$, necrotic cells, often with a very convoluted lysed nucleus, harboured a few intranuclear and cytoplasmic empty capsids, or capsids with abnormal cores. Spaces left by lysed cells contained necrotic debris, nucleocapsids and virions (Fig. 2b, c). A different process of cell death was observed at stage VI. In fected nuclei were homogeneous in content and dense, and the cytoplasm comprised dense background substance, particularly ribosomes, and organelle remnants including concentric arrays of endoplasmic reticulum (ER). A few viral particles at different stages of development were apparent in many of these hyperdense cells (Fig. 17), which were frequently grouped in foci (Fig. 2d).

These stages were applicable to most infected cells, the main exception being cells in which cytoplasmic stages occurred, but few nuclear stages were apparent. It appeared that these cells produced few virions, but that these viruses were possibly produced continuously over a long period. In some larvae, many adjacent cells showed synchronous replication (Fig. 2b). In others development was asynchronous in adjacent cells. This biased the numbers in Table 1, which should only be taken as a general indication of the stages present. Even so, it appeared that early stages occurred at $4 \mathrm{~h}$, nuclear and cytoplasmic stages were present at $24 \mathrm{~h}$ and were abundant by $48 \mathrm{~h}$, after which most larvae died. However, infected lysing and hyperdense cells were also present during the first $24 \mathrm{~h}$ 

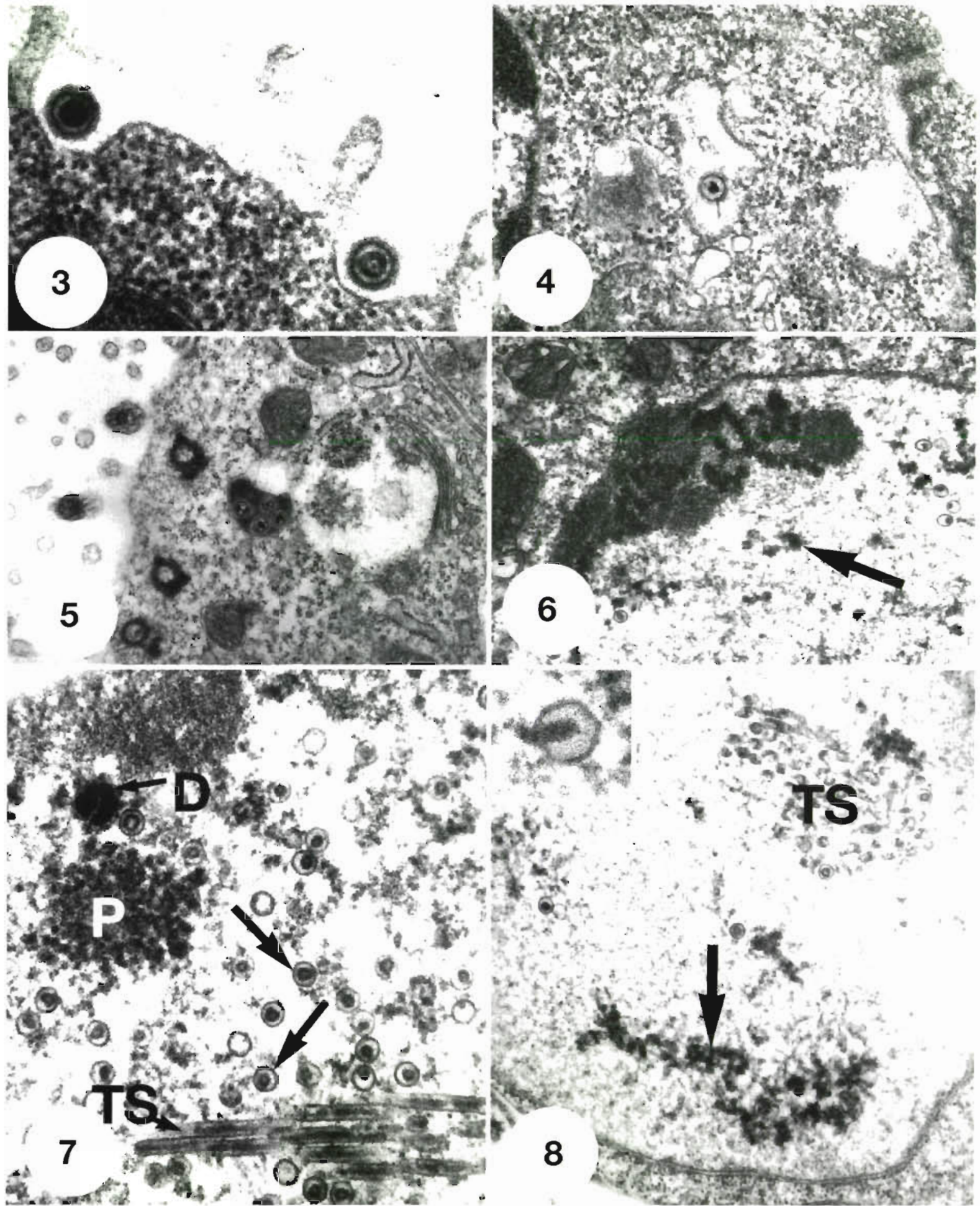

Figs. 3 to 8. Herpes-like virus in Tiostrea chilensis. Early stages of replication at 16 to $18^{\circ} \mathrm{C}$. Fig. 3 . Vinons in indentations of the cell surface between mantle epithelial cell microvill1; apparently pnor to entry $(2 \mathrm{~d}) ; \times 77140$. Fig. 4 . Coated nucleocapsid in the cytoplasm of a mantle epithelial cell with a normal nucleus (stage II) $(4 \mathrm{~h}) ; \times 45000$ Fig. 5 . Apical surface of a cllated digestive tract epithelial cell showing a lysosome-hke body containing 4 nucleocapsids (stage II) $(2 \mathrm{~d}) ; \times 22200$ Flg. 6 Disaggregatıon of the nucleolus of an infected interstitial cell into fibrillar and granular components Some capsids with partial cores he next to putative viral DNA (arrow) (stage III) $(2 \mathrm{~d}) ; \times 23130 \mathrm{Fig} .7$. Edge of nucleus of an interstıtlal cell showing perichromatin granules (P), a dense body (D), tubular structures (TS), and lucent core capsids (LCC) (arrows) (stage III) ( 2 d); $\times 45710$ Fig. 8 . TS, LCC, and flocculent material thought to be viral DNA (arrow) (2 d): $\times 25560$. Inset. encapsidation of dense material (stage III) (2 d). $\times 106120$ 


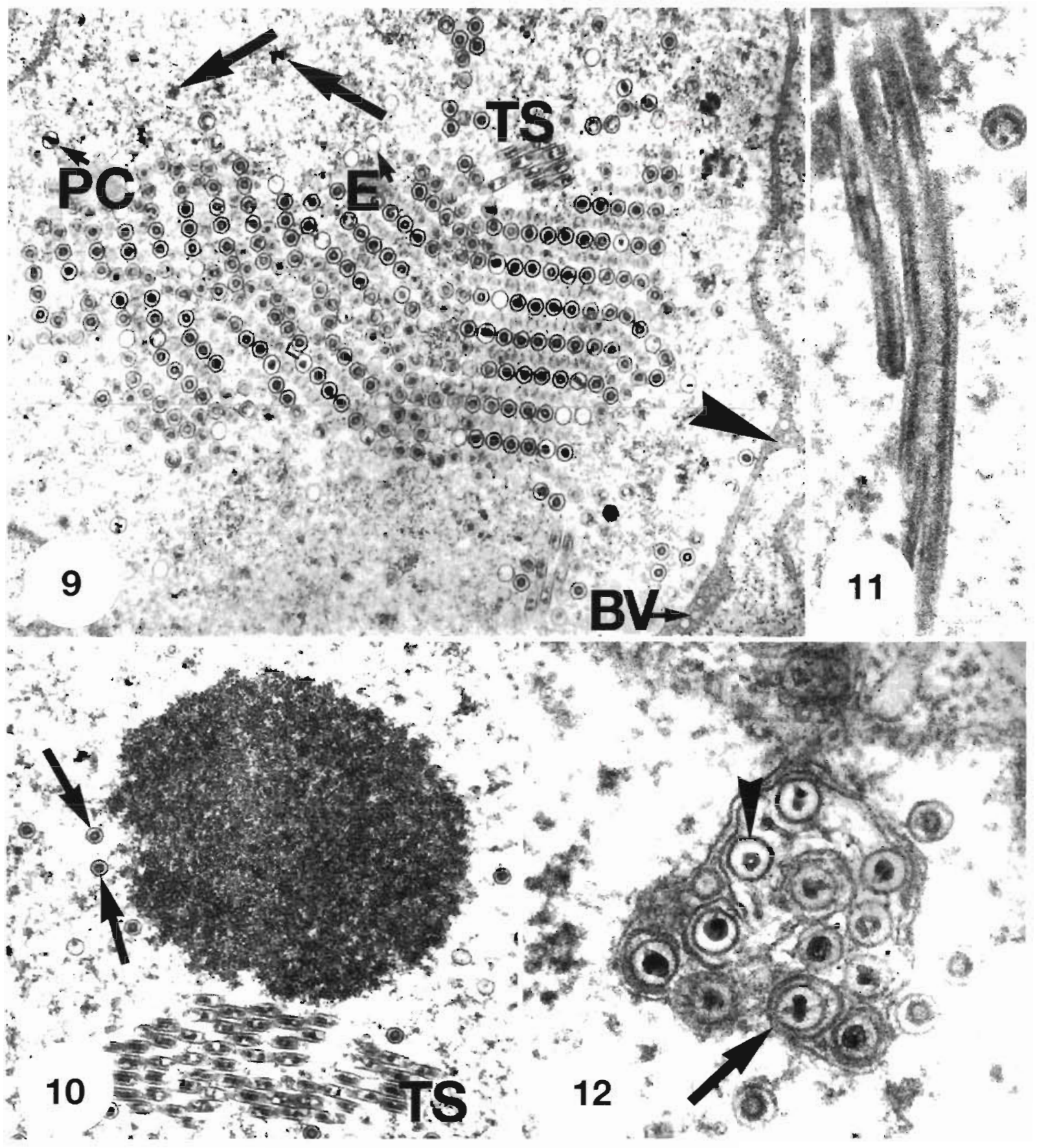

Figs 9 to 12 Herpes-like virus in Tiostrea chilensis Intranuclear features at stage III (Figs. 9 to 11) and stage IV (Fig. 12) (16 to $18^{\circ} \mathrm{C}$ ) Fig. 9 Paracrystalline array of manly lucent cores (LCC). Also present are. empty capsids (E), capsids with partial cores (PC), tubular structures (TS), putative viral DNA (arrows), dark matrix in the nuclear membrane (arrowhead) containing bilaminar vesıcles $(B V)(3 \mathrm{~d}), \times 27380$. Fig 10 . Ovold fine granular mass, TS, and LCC (arrows) (stage III) $(2 \mathrm{~d}) ; \times 26920$. Fig. 11. TS 100 to $65 \mathrm{~nm}$ in diameter with a $35 \mathrm{~nm}$ inner tubule $(1 \mathrm{~d})$ : $\times 68570 \mathrm{Fig} .12$ Intranuclear sac surrounded by LCC, containing nucleocapsids with (arrow) and without (arrowhead) envelopes (2 d), $\times 71140$

\section{Pathogenesis and virogenesis at 24 to $27^{\circ} \mathrm{C}$}

Except for initial entry stages and lysed cells at $4 \mathrm{~h}$. and a cell at stage I at $8 \mathrm{~h}$, neither viral developmental stages or cytopathology suggesting the presence of virus were observed until $48 \mathrm{~h}$ (Table 1). At that time, of a few dense cells seen with enlarged hypochromatic nuclei, one was observed with perinuclear capsids and abnormal membranous inclusions in the nucleoplasm (Fig 18). 


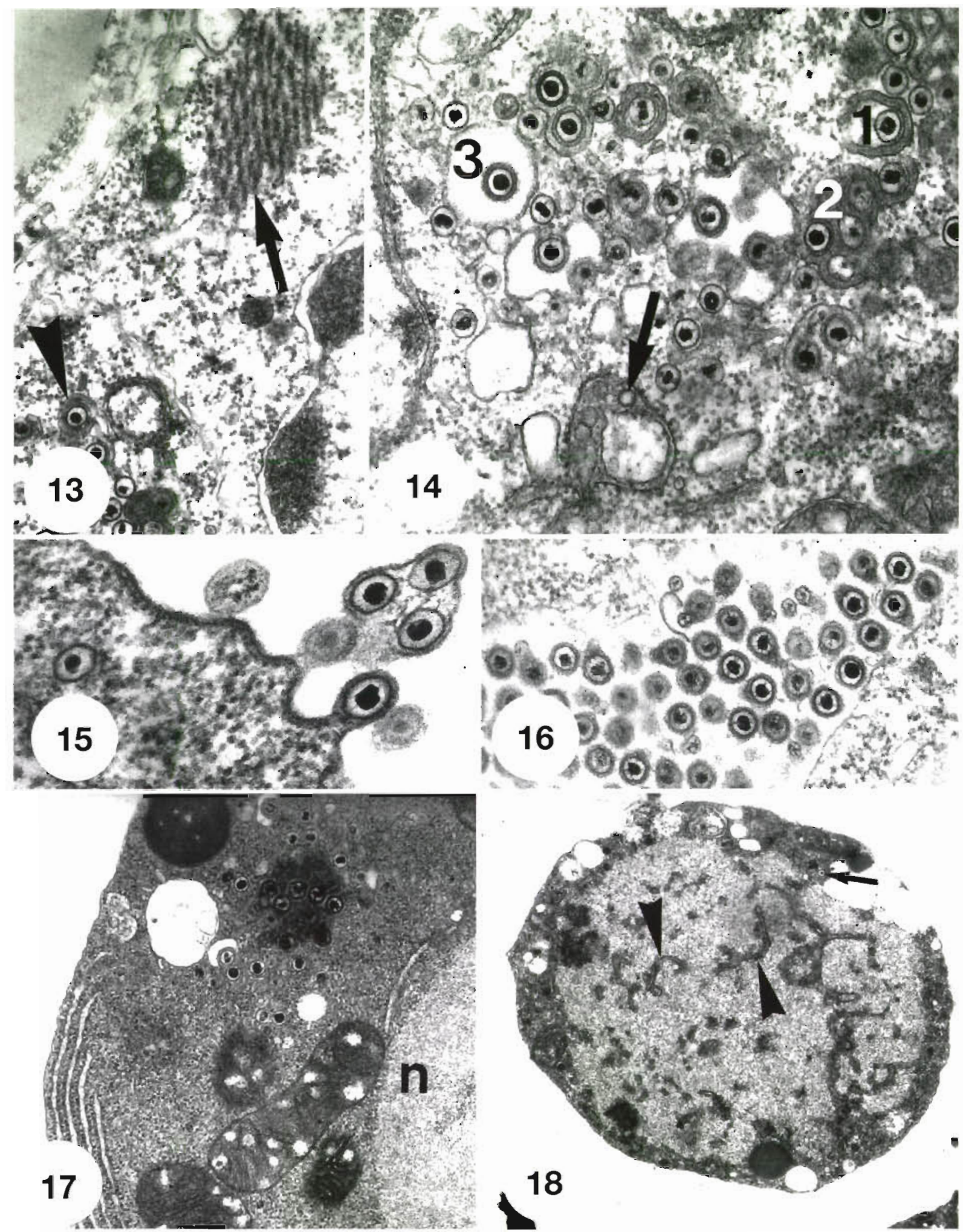

Figs. 13 to 18 . Herpes-like virus in Tiostrea chilensis Stages IV to VI at 16 to $18^{\circ} \mathrm{C}$, except Fig $18\left(24\right.$ to $\left.27^{\circ} \mathrm{C}\right)$ Fig. $13 . \mathrm{Cytoplas}$ mic dense filaments (arrow), and nucleocapsids acquinng a tegument (arrowhead) (stage IV) (2 di, $\times 39000$ Fig. 14. 1: Nucleocapsids by vermiform or circular vesicles, 2 . enveloped nucleocapsids in vesicles with a dense matrix; or 3 : lucent vesıcles. Note the dense matrix in rough endoplasmic retıculum (rER) containing bilaminar vesicles (arrow) (stage IV) (2 d); $\times 58150$. Fig. 15. Virion apparently budding from the plasma membrane of a mantle epithelial cell (stage IV) (2 d); $\times 67060$. Fig. 16 Extra-

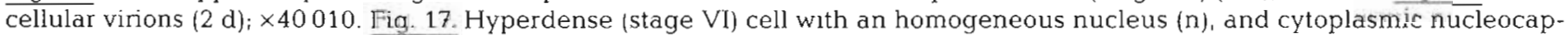
sids, some apparently arrested while budding into vesicles $(16 \mathrm{~h}), \times 23370$. Fig. 18 . Dense cell showing karyolysis and intranuclear membranes (arrowheads) probably due to convolutions of the nuclear membrane. An empty capsid and a nucleocapsid lie at the edge of the nucleoplasm (arrow) ( $2 \mathrm{~d}$ ). $\times 13940$ 


\section{DISCUSSION}

The virions observed here have the features of herpesviruses of higher vertebrates, and as previously reported from oysters (Table 2) (Hine et al. 1992, Hine \& Thorne 1997). Some of the features previously reported in replication of oyster herpes-like viruses were seen in Tiostrea chilensis (Table 3). The initial wavy folding of the nuclear membrane, and paracrystalline arrays of empty capsids have been reported from Crassostrea gigas (Renault et al. 1994b), but the large paracrystalline arrays of LCC have not. Ovoid bodies of fine granular material occur in C. gigas and Ostrea angasi infections (Hine et al. 1992, Hine \& Thorne 1997). Although LCC in oysters have not been distinguished from nucleocapsids with mature toroidai cores, they have been illustrated in C. gigas infections (Renault et al. 1994a, b). The dense body with granular content resembles the groups of dark flecks reported from O. angasi (Hine \& Thorne 1997). Envelopment in perinuclear cisternae, intranuclear sacs, and in ovoid cytoplasmic vesicles have also been reported (Hine et al. 1992, Comps \& Cochennec 1993, Hine \& Thorne 1997 ) and are common features of herpesviruses.

Virogenesis in Tiostrea chilensis differs from that reported in other oysters in: (1) replication at ambient temperatures, (2) partial disaggregation of the nucleolus, (3) the presence of TS, (4) LCC in paracrystalline arrays, (5) the dark matrix and vesicles in the nuclear membrane, and the continuity of the nuclear mem- brane with IER, (6) bundles of cytoplasmic filaments, and (7) budding from the cell surface. Some of these features are compared between oyster species, and with well-characterized herpesviruses in Table 3. As noted by Farley et al. (1972), oyster viruses resemble ranid herpesvirus 1 (Lucké tumour virus). In this study, in particular, replication at lower temperatures but inhibition of replication at higher temperatures, epitheliotropism, the partial disaggregation of the nucleolus, TS, LCC, paracrystalline arrays, and cytoplasmic filaments of 30 to $35 \mathrm{~nm}$ diameter resemble replication of the Lucké tumour virus (Lunger et al. 1965, Mizell et al. 1968, Stackpole \& Mizell 1968, Stackpole 1969, Skinner \& Mizell 1972, Wong \& Tweedell 1975, McKinnell \& Cunningham 1982). The TS of $T$. chilensis herpes-like virus were composed of an outer tubule with helical substructure that was occasionally $100 \mathrm{~nm}$, but usually $65 \mathrm{~nm}$, in diameter, containing a tubular core $35 \mathrm{~nm}$ in diameter. These resemble the 95,65 , and $35 \mathrm{~nm}$ diameters respectively reported for TS in ranid herpesvirus 1 infections (Stackpole \& Mizell 1968, Stackpole 1969, Skinner \& Mizell 1972). The subunits with a helical configuration have been identified as capsomeres, and it appears that LCC form from these capsomere tubules (Stackpole \& Mizell 1968, Tumilowicz \& Powell 1990). In turn, LCC appeared to develop into empty capsids. This interpretation is supported by the observations of Weiland et al. (1986) that electron-lucent capsids in murine cytomegalovirus (CMV) infection develop to empty

Table 2. Comparison of reported bivalve herpes-like viruses. Tiostrea chilensis data based on 50 measurements. MNC: mature nucleocapsid

\begin{tabular}{|c|c|c|c|c|}
\hline Species/cell type & $\mathrm{MNC}$ & Virions & $\begin{array}{l}\text { Virions } \\
\text { tailed }\end{array}$ & Study \\
\hline \multicolumn{5}{|l|}{ Crassostrea gigas larvae and spat } \\
\hline Paraspherical cells & $70 \pm 2$ & $90 \pm 5$ & & Nicolas et al. (1992) \\
\hline Unidentified/myocytes & $97 \pm 4$ & $131 \pm 9$ & + & Hine et al. (1992) \\
\hline Connective cells of the velum & $72-75$ & & & Le Deuff et al. (1994) \\
\hline Interstitial cells/myocytes & 80 & & & Renault et al. (1994a) \\
\hline $\begin{array}{l}\text { Connective cells of velum mantle, } \\
\text { gills. In myocytes, haemocytes }\end{array}$ & $70-75$ & 120 & & Renault et al. (1994b, 1995) \\
\hline Velar interstitial and epithelial cells & 80 & & & Le Deuff et al. (1996) \\
\hline \multicolumn{5}{|l|}{ Crassostrea virginica adults } \\
\hline Cells around haemolymph sinuses & $70-90$ & & & Farley et al. (1972) \\
\hline \multicolumn{5}{|l|}{ Ostrea edulis spat } \\
\hline Interstitial cells, haemocytes, fibroblasts & 80 & $140-150$ & + & Comp \& Cochennec (1993) \\
\hline \multicolumn{5}{|l|}{ Ostrea angasi adults } \\
\hline Haemocytes, fibroblasts & $98 \pm 4$ & $135-140$ & + & Hine \& Thorne (1997) \\
\hline \multicolumn{5}{|l|}{ Tiostrea chilensis larvae and spat } \\
\hline $\begin{array}{l}\text { Interstitial cells, mantle } \\
\text { and digestive tract epithelial cells }\end{array}$ & $101 \pm 9$ & $130 \pm 11$ & & This study \\
\hline
\end{tabular}


Table 3. Comparison between $\alpha$-herpesviruses, $\beta$-herpesviruses, Lucké herpesvirus and oyster herpesviruses

\begin{tabular}{|c|c|c|c|c|c|c|}
\hline & $\alpha$ & $\beta$ & $\begin{array}{l}\text { Lucké } \\
\text { herpesvirus }\end{array}$ & $\begin{array}{c}\text { Tiostrea } \\
\text { chilensis }\end{array}$ & $\begin{array}{l}\text { Ostrea } \\
\text { angasi }\end{array}$ & $\begin{array}{c}\text { Crassostrea } \\
\text { gigas }\end{array}$ \\
\hline Nuclear membrane folding & $+5.9,11$ & $+{ }^{20}$ & $+^{8,16}$ & +25 & - & $\pm^{22}$ \\
\hline Reduplicated nuclear membrane & $+^{5,9,11}$ & - & - & - & - & - \\
\hline Nucleolar disaggregation & $+7,9.13$ & - & $\pm^{4}$ & $\pm^{25}$ & - & - \\
\hline Aligned fibrils (rods) & $\pm^{9,13}$ & $\pm^{14}$ & - & - & $t^{24}$ & - \\
\hline Skein-like viral matrix & -11 & $+2,11,14,17$ & - & - & $++^{24}$ & - \\
\hline Dark flecks or mass & $++^{11.13}$ & $\pm^{16}$ & - & $+{ }^{25}$ & +24 & - \\
\hline Intranuclear tubules & +3.5 & $+14,19,21$ & $+6.8,10$ & $+{ }^{25}$ & - & $-^{\mathrm{a}}$ \\
\hline Lattice tubules & $+3,5,7$ & - & - & - & - & - \\
\hline Paracrystalline arrays & $t^{3.5,7.9 .18}$ & $\pm^{2}$ & $t^{1,8,10}$ & $+t^{25}$ & - & $\pm^{22}$ \\
\hline Latency in central nervous system & $+{ }^{12,23}$ & - & - & ? & ? & ? \\
\hline Latency in leukocytes & - & $++^{23}$ & - & ? & $+?^{24}$ & ? \\
\hline Latency in epithelium & - & - & $+{ }^{15}$ & ? & ? & ? \\
\hline Cytoplasmic filaments & - & - & $+^{1.8,10,15}$ & $t^{25}$ & - & - \\
\hline \multicolumn{7}{|c|}{ 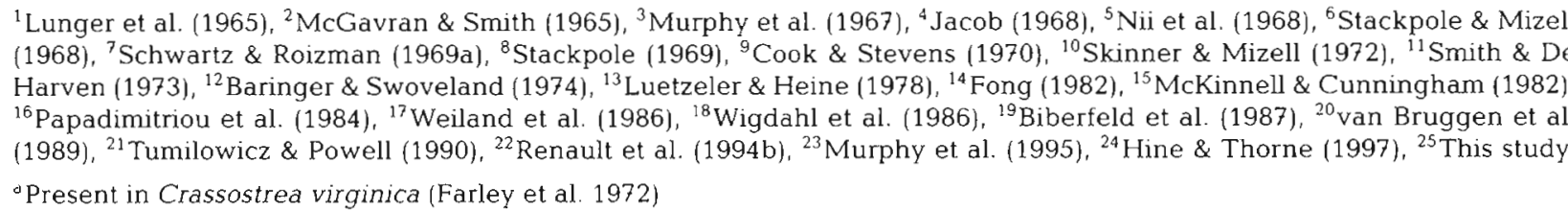 } \\
\hline
\end{tabular}

capsids. Similarly, empty capsids appear after LCC in herpes simplex virus (HSV) infection (Nii et al. 1968), and the lucent cores of LCC are not composed of DNA (Friedmann et al. 1975).

The data in Table 1 suggest that at 16 to $18^{\circ} \mathrm{C}$ virogenesis may be initiated following removal of veligers from the brood chamber with replication at $24 \mathrm{~h}$, abundant virion production at $48 \mathrm{~h}$, and larval death and reduced viral production at $72 \mathrm{~h}$. This course of disease is similar to the 2 to $4 \mathrm{~d}$ in Crassostrea gigas mentioned by Le Deuff et al. $(1994,1996)$, but more rapid than the 8 to $10 \mathrm{~d}$ usually observed in C. gigas at $\sim 25^{\circ} \mathrm{C}$ (Hine et al. 1992, Renault et al. 1994b, Le Deuff et al. 1996). It is intermediate in time between the 8 to $20 \mathrm{~h}$ needed for HSV to reach high virion production (Friedmann et al. 1975), and the 4 to $9 \mathrm{~d}$ usually required for $\mathrm{CMV}$ virion production (Smith \& De Harven 1973). However, CMV development in macrophages can be as rapid as $24 \mathrm{~h}$ for envelopment in the perinucear cisterna, and cytoplasmic stages at 48 h (van Bruggen et al. 1989). It also resembles the $72 \mathrm{~h}$ replication time of ranid herpesvirus 1 (Stackpole 1969). The occurrence of paracrystalline arrays in some cells after 2 to $3 \mathrm{~d}$, and in hyperdense cells, is similar to their occurrence late in the infection cycle of HSV (Nii et al. 1968, Schwartz \& Roizman 1969a) and ranid herpesvirus 1 (Stackpole 1969).

Virus replication stages II to V resemble those of herpesviruses. The nucleocapsids in secondary lysosomes of digestive epithelial cells may represent endocytosis and destruction of virions in the gut. Similar association between nucleocapsids and lysosomes has been reported in varicella-zoster virus (VZV; Gershon et al. 1973), CMV (Lussier et al. 1974), and ranid herpesvirus 1 (Stackpole 1969) infection. However in VZV, nucleocapsids replicating in the host cell were enclosed in Golgi vesicles and lysosomes, and were inactivated prior to egress. Similarities in structure and appearance between the nuclear membrane and rER in this study, and ducts leading from the perinuclear cisterna in HSV infection (Schwartz \& Roizman 1969b), suggest that the oyster herpes-like virus may effect egress by this route. However, it appeared necessary for the nucleocapsids to pass into vesicles containing dense material, thus acquiring a tegument, before envelopment and shedding. It may be that the dense matrix and bilaminar vesicles in dilated perinuclear and $r E R$ cisternae permit tegument acquisition and envelopment in the dilated ducts, prior to egress from them.

Some hyperdense (stage VI) cells were infected, but similar condensation occurred in apparently uninfected cells at death. Viral levels in the nuclear and cytoplasmic compartments of hyperdense cells were similar to those seen in some stage IV cells in which all developmental stages were present at low levels. It may be that infection can follow a chronic/low virogenesis course leading to hyperdense cells, or an acute/high virogenesis course leading to cell lysis. Quantitative differences may occur if different cell types are infected, as in fibroblasts and neurons infected with VZV (Wigdahl et al. 1986). If so, different cell types may explain asynchronous replication among some groups of cells, and synchronous replication may occur among groups of the same cell type. 
Veligers dying at 16 to $18^{\circ} \mathrm{C}$ had extensive lesions associated with high levels of virogenesis, but in the fourth experiment at 16 to $18^{\circ} \mathrm{C}$, where there was no mortality, there were no indications of viral infection. Mortality at 24 to $27^{\circ} \mathrm{C}$ was similar to that at 16 to $18^{\circ} \mathrm{C}$, but the cause of mortality was not apparent. The elevated temperatures $\left(24\right.$ to $\left.27^{\circ} \mathrm{C}\right)$ may be at the upper limit of tolerance for a cold temperate oyster, such as New Zealand Tiostrea chilensis, which in the wild survives at 6 to $25^{\circ} \mathrm{C}$ (Buroker et al. 1983). If so, lack of replication at 24 to $27^{\circ} \mathrm{C}$ may be due to temperature making host cells abnormal and non-permissive. Interestingly, although mortality rates among herpesvirusinfected French Crassostrea gigas larvae held at 25 to $26^{\circ} \mathrm{C}$ were higher than at 22 to $23^{\circ} \mathrm{C}$, at which temperature viral replication was not observed, the latter group also experienced relatively high progressive mortalities (Le Deuff et al. 1996). Dense intranuclear bodies were the only alteration seen in $C$. gigas larvae at 22 to $23^{\circ} \mathrm{C}$. They were interpreted as being either an expression of viral protein in a latent infection or as representing an aborted viral cycle (Le Deuff et al. 1996). The cell with an enlarged hypochromatic nucleus and capsids seen at $48 \mathrm{~h}$ at 26 to $27^{\circ} \mathrm{C}$ in this study may also represent latent infection, as $\alpha$-herpesviruses may establish latent infections at supraoptimal temperatures (Russell \& Preston 1986). In HSVinfected rabbits, 1 or 2 hyperdense cells per ganglion, with a few intranuclear empty capsids, putative cores, and nucleocapsids have been reported from explanted trigeminal ganglia, the site of latent infection (Baringer \& Swoveland 1974).

Stage I cells may provide further evidence of latency. Empty capsids and LCC occurred in normal host cell nuclei, whereas nuclear enlargement and heterochromatin margination normally preceded capsid formation, as in other herpesviruses (Murphy et al. 1995). The LCC and empty capsids are unlikely to derive from recent entry as unenveloped nucleocapsids move from the point of entry to a nuclear pore where the capsid remains and only viral DNA enters the nucleus (Lycke et al. 1988, Murphy et al. 1995). Stage II is consistent with this process. Normal cells with intranuclear LCC and empty capsids were patently infected, but infection appeared to be static. In latency, the viral genome may be integrated into the host cell genome or in free forms inside the nucleus without viral expression, or low levels of virus might be produced and shed in excretions (Murphy et al. 1995). The few capsids in apparently normal cells are similar to the few empty capsids, nucleocapsids and pleomorphic capsids observed in neurons infected with VZV (Wigdahl et al. 1986). Reactivation from latency and subsequent virogenesis may occur under conditions of stress, such as removal from the brood chamber in this study, or ele- vated temperatures (Le Deuff et al. 1996). Similarly, stress reactivates HSV and VZV infections in humans.

The virus in Tiostrea chilensis occurred in the absence of Crassostrea gigas herpesvirus (data not shown), and the $T$. chilensis virus shows several qualitative differences in replication to herpesviruses in $C$. gigas and Ostrea angasi (Table 3). Differences in replication in relation to host cell type or virus strain are often quantitative (Schwartz \& Roizman 1969a), but differences between virus species are usually qualitative. Differences in replication in $T$. chilensis are unlikely to be due to lower temperature, as herpesvirus replication is usually consistent at an optimal temperature with mutant strains showing incomplete replication outside that range (Atkinson et al. 1978). However, it would be premature to conciude that similarities in the uiltrastructure of replication between the virus reported here and ranid herpesvirus 1 necessarily mean they are more closely related to each other than are the herpesviruses of oysters. Many factors influence the details of replication, such as host species, temperature, and the cell types involved. A more experimental approach and molecular techniques are needed to clarify the inter-relationships of oyster herpesviruses, and their affinities with herpesviruses of vertebrates.

Acknowledgements. This research was funded by the New Zealand Ministry of Fisheries through project FDI701. The work of Barry Martin of the Electron Microscope Facility, Victoria University of Wellington, is appreciated. We are also grateful to Lisa Northcote for assistance with manuscript preparation

\section{LITERATURE CITED}

Atkinson MA, Barr S, Timbury MC (1978) The fine structure of cells infected with temperature-sensitive mutants of herpes simplex type 2. J Gen Virol 40:103-119

Baringer JR, Swoveland P (1974) Persistent herpes simplex virus infection in rabbit trigeminal ganglia. Lab Invest 30 : $230-240$

Biberfeld P, Kramarsky B, Salahuddin SZ, Gallo RC (1987) Ultrastructural characterization of a new human B lymphotropic DNA virus (human herpesvirus 6) isolated from patients with lymphoproliferative disease. JNCI (J Natl Cancer Inst) 79:933-941

Buroker NE, Chanley P, Cranfield HJ, Dinamani P (1983) Systematic status of two oyster populations of the genus Tiostrea from New Zealand and Chile. Mar Biol 77: $191-200$

Comps M, Cochennec N (1993) A herpes-like virus from the European oyster Ostrea edulis L. J Invertebr Pathol 62: 201-203

Cook ML, Stevens JG (1970) Replication of varicella-zoster virus in cell culture: an ultrastructural study. J Ultrastruct Res 32:334-350

Farley CA, Banfield WG, Kasnic G, Foster WS (1972) Oyster herpes-type virus. Science 178:759-760

Fong CKY (1982) Ultrastructural localization of cytomegalo- 
virus DNA synthesis in infected guinea-pig cells. J Gen Virol 60:235-245

Friedmann A, Coward JE, Rosenkranz HS, Morgan C (1975) Electron microscopic studies on assembly of herpes simplex virus upon removal of hydroxyurea block. J Gen Virol 26:171-181

Gershon A, Cosio L, Brunell PA (1973) Observations on the varicella-zoster virus in human diploid cells. J Gen Virol 18:21-31

Hine PM, Thorne T (1997) Replication of herpes-like viruses in haemocytes of adult flat oysters Ostrea angasi (Sowerby, 1871): an ultrastructural study. Dis Aquat Org 29:189-196

Hine PM, Wesney B, Hay BE (1992) Herpesviruses associated with mortalities among hatchery-reared larval Pacific oysters Crassostrea gigas. Dis Aquat Org 12:135-142

Jacob J (1968) Involvement of the nucleolus in viral synthesis in the cells of primary renal tumors of leopard frogs. Cancer Res 28:2126-2136

Le Deuff RM, Nicolas JL, Renault T, Cochennec N (1994) Experimental transmission of a herpes-like virus to axenic larvae of Pacific oyster, Crassostrea gigas. Bull Eur Ass Fish Pathol 14:69-72

Le Deuff RM, Renault T, Cochennec N (1995) Antibodies specific for channel catfish virus cross-react with Pacific oyster, Crassostrea gigas, herpes-like virus. Vet Res 26: 526-529

Le Deuff RM, Renault T, Gérard A (1996) Effects of temperature on herpes-like virus detection among hatchery-reared larval Pacific oyster Crassostrea gigas. Dis Aquat Org 24: $149-157$

Luetzeler J, Heine U (1978) Nuclear accumulation of filamentous herpes simplex virus DNA late during the replicative cycle. Intervirology 10:289-299

Lunger PD, Darlington RW, Granoff A (1965) Cell-virus relationships in the Lucké renal adenocarcinoma: an ultrastructural study. Ann NY Acad Sci 126:289-314

Lussier G, Berthiaume L, Payment P (1974) Electron microscopy of murine cytomegalovirus: development of the virus in vivo and in vitro. Arch Gesamte Virusforsch $46: 269-280$

Lycke E, Hamark B, Johansson M, Krotochwil A, Lyke J, Svennerholm B (1988) Herpes simplex virus infection of the human sensory neuron. An electron microscopy study. Arch Virol 101:87-104

McGavran MH, Smith MG (1965) Ultrastructural, cytochemical and microchemical observations on cytomegalovirus (salivary gland virus) infection of human cells in tissue culture. Exp Mol Pathol 4:1-10

McKinnell RG, Cunningham WP (1982) Herpesviruses in metastatic Lucké renal adenocarcinoma. Differentiation $22: 41-46$

Mizell M, Stackpole CW, Halpern S (1968) Herpes-type virus recovery from 'virus-free' frog kidney tumors. Proc Soc Exp Biol Med 127:808-814

Murphy FA, Fauquet CM, Bishop DHL, Ghabrial SA, Jarvis AW, Martelli GP, Mayo MA, Summers MD (1995) Virus taxonomy: classification and nomenclature of viruses: sixth report of the International Committee on Taxonomy of Viruses. Arch Virol Suppl 10:586p

Murphy FA, Harrison AK, Whitfield SG (1967) Intranuclear

Editorial responsibility: Albert Sparks,

Seattle, Washington, USA formation of filaments in Herpesvirus hominis infection of mice. Arch Gesamte Virusforsch 21:463-468

Nicolas JL, Comps M, Cochennec N (1992) Herpes-like virus infecting Pacific oyster larvae, Crassostrea gigas. Bull Eur Ass Fish Pathol 12 (1):11-13

Nii S, Morgan C, Rose HM (1968) Electron microscopy of herpes simplex virus II. Sequence of development. J Virol $2: 517-536$

Papadimitriou JM, Shellam GR, Robertson TA (1984) An ultrastructural investigation of cytomegalovirus replication in murine hepatocytes. J Gen Virol 65:1979-1990

Renault T, Cochennec N, Le Deuff RM, Chollet B (1994a) Herpes-like virus infecting Japanese oyster (Crassostrea gigas) spat. Bull Eur Ass Fish Pathol 14 (2):64-66

Renault T, Le Deuff RM, Cochennec N, Chollet B, Maffart P (1995) Herpesviruses associated with high mortality levels in larvae and spat of Pacific oysters, Crassostrea gigas: a comparative study, the thermal effects on virus detection in hatchery-reared larvae, reproduction of the disease in axenic larvae. Vet Res 26:539-543

Renault T, Le Deuff RM, Cochennec N, Maffart P (1994b) Herpesviruses associated with mortalities among Pacific oyster, Crassostrea gigas, in France-Comparative study. Revue Méd Vét 145:735-742

Russell J, Preston CM (1986) An in vitro latency system for herpes simplex virus type 2. J Gen Virol 67:397-403

Schwartz J, Roizman B (1969a) Similarities and differences in the development of laboratory strains and freshly isolated strains of herpes simplex virus in $\mathrm{HEp}-2$ cells: electron microscopy. J Virol 4:879-889

Schwartz J, Roizman B (1969b) Concerning the egress of herpes simplex virus from infected cells: electron and light microscope observations. Virology 38:42-49

Skinner MS, Mizell M (1972) The effect of different temperatures on herpesvirus induction and replication in Lucké tumor explants. Lab Invest 26:671-681

Smith JD, De Harven E (1973) Herpes simplex virus and human cytomegalovirus replication in WI-38 cells. I. Sequence of viral replication. J Virol 12:919-930

Stackpole CW (1969) Herpes-type virus of the frog renal adenocarcinoma. 1. Virus development in tumor transplants maintained at low temperature. J Virol 4:75-93

Stackpole CW, Mizell M (1968) Electron microscopic observations on herpes-type virus-related structures in the frog renal adenocarcinoma. Virology 36:63-72

Tumilowicz JJ, Powell BB (1990) Role of intranuclear sacs, intrasaccate tubes, and cytoplasmic dense bodies in the structural completion of cytomegalovirus. Intervirology 31:14-22

van Bruggen I, Price P, Robertson TA, Papadimitriou JM (1989) Morphological and functional changes during cytomegalovirus replication in murine macrophages. J Leukocyte Biol 46:508-520

Weiland F, Keil GM, Reddehase MJ, Koszinowski UH (1986) Studies on the morphogenesis of murine cytomegalovirus. Intervirology 26:192-201

Wigdahl B, Rong BL, Kinney-Thomas E (1986) VaricellaZoster virus infection of human sensory neurons. Virology 152:384-399

Wong WY, Tweedell KS (1975) Viral carcinogenesis in a pronephric cell line. Am J Pathol 80:143-152

Submitted: June 18, 1997; Accepted: January 9, 1998

Proofs received from author(s): March 18, 1998 